\title{
The Implementation Effectiveness of the K3RS Program with Achievement of Compliance on Hospital Accreditation Standards at Dr. R. M. Djoelham Hospital in Binjai of 2019
}

\author{
Melda Sari Tarigan ${ }^{1}$, Gerry Silaban $^{2}$, Zulfendri $^{2}$ \\ ${ }^{1}$ Master Student in Universitas Sumatera Utara, Medan, Indonesia \\ ${ }^{2}$ Lecturer in Universitas Sumatera Utara, Medan, Indonesia \\ Email: drmeldatarigan@gmail.com
}

\begin{abstract}
:
This study deals with the implementation effectiveness of the k3rs program with achievement of compliance on hospital accreditation standards in Dr. R. M. Djoelham Hospital in Binjai of 2019. This research was conducted at Dr. R. M. Djoelham Regional Hospital in Binjai City because the efforts in achieving accreditation have not been met in accordance with K3RS standards. Based on the results of the study it can be concluded that K3RS (Occupational Health and Safety) implementation in Dr. R. M. Djoelham Regional Hospitas of Binjai City based on category communication is good. This is indicated by despite the lack of budget in conducting socialization and simulation, but they continue to carry out socialization to related units, especially those with high risk with K3RS.
\end{abstract}

Keywords:

K3RS program; hospital accreditation standards; Dr. R. M. Djoelham Hospital

\section{Introduction}

Minister of Health Regulation number 12 of 2012 concerning Hospital Accreditation, namely K3RS (Occupational Health and Safety) is a part in improving the quality and service in hospitals. This K3RS in the Hospital Management standard group on Facility Management and Safety. Through this Facility and Safety Management, K3RS has policies, guidelines, SOPs and also programs from the K3RS. Based on the 2012 Hospital Accreditation Commission, the K3RS program implemented by Dr. R.M. Djoelham Binjai Regional Hospital Coverage: 1. Disaster Management Program, 2. Management of Hazardous Materials and Goods, 3. Fire Control Prevention, 4. Safety of Visitor Patients and Officers, 5. Employee Safety and Health, 6. Hospital Environmental Health, 7. Hospital Sanitation, 8. Management, Recovery and Certification of Facilities and Infrastructure, 9. Management of Solid, Liquid and Gas Waste, 10. Training and Education K3.

With the existence of the K3RS program that is adapted to the hospital accreditation standards, all of these programs must be implemented, and approved of 10 of these programs not implemented, it can support the implementation of the program that does not meet hospital accreditation standards, so it cannot be used effectively using the K3RS program. This causes an increase in occupational accidents and illness due to uncomfortable work and ultimately results in poor health being organized.

Ramli (2006) states that K3 replaces losses in workplace accidents and other people or business inefficiencies, ensuring the fulfillment of norms, standards and regulations of $\mathrm{K} 3$ in the company, as work units and labor in $\mathrm{K} 3$ work relationships, and management tools in carrying out functions the control is in the K3 aspect. K3 must be part of business activities and strategic plans that are carried out on the basis of company plans. The main objectives of 
K3 implementation are to overcome savings, save costs, and use resources efficiently (Tweedy, 2005).

Dr. R.M. Djoelham Binjai Regional Hospital with Class B Hospital is a Regional Hospital owned by Binjai City Government which provides health services to the general public and is also a referral Hospital in Binjai City. Organizational structure. Dr. Regional General Hospital Director supports 3 deputy directors namely deputy director general and human resources, deputy finance director and deputy minister director have a variety of services namely Internal Medicine, ENT Poly, Cardiac Poly, TB Poly, HIV Poly, Eye Poly, Surgery Poly, Orthopedics Poly, Neurology Poly, PKBRS Poly, Skin and Genital Poly, Child Poly, Radiology Installation, Laboratory Installation, Hemodialysis Installation, and Inpatient, connecting several preliminaries in Dr. RM Djoelham Regional Hospital Implemented in accordance with Hospital accreditation, but the implementation of the K3RS program still requires approval relating to running K3RS in Dr. R. M. Djoelham Regional Hospital appears from the actions and actions of employees who are not in accordance with the SOP.

In accordance with the results of the accreditation verification from the KARS Team in 2019 it was found that there were debates and problems in each standard assessment element, namely: 1) human resources (staff) were not yet in accordance with the K3RS change assistance program according to the obstructed elements, 2) calibration activities for all medical devices also did not run in a limited manner because of limited budgets 3) the implementation of cooperative relations not yet related specifically to the maintenance of emergencies, epidemics and disasters. 4) Reports on the results of activities have not been carried out periodically.

On the other hand the K3RS program has also not been able to run optimally because the infrastructure and the hospital still do not meet the K3RS standards. Another obstacle is also due to the lack of commitment from all employees of Dr. R. M. Djoelham Binjai Regional Hospital to run the K3RS program.

\section{Review of Literature}

\subsection{Work Safety}

According to Bennet N.B. Silalahi and Rumondang (Widodo, 2015), safety is an effort to prevent any unsafe acts or conditions that can result in accidents. Work safety is a form of circumstance that prevents mistakes and damage to work done by workers/employees.

Work safety is intended to provide protection to the workforce, which involves aspects of safety, health, maintenance of work morale, treatment according to human dignity and religious morals. This is intended so that workers can safely do their jobs in order to improve work output and work productivity. Thus, the workers must obtain guarantees of safety and health protection in every day work implementation (Tarwaka, 2014).

According to Law Number 1 of 1970 Chapter III article 3 concerning work safety, the following conditions for work safety are stated:

a. Prevent and reduce accidents

b. Prevent, reduce and extinguish fires

c. Prevent and reduce the danger of blasting

d. Give an opportunity or a way to save yourself when a fire or other dangerous events occur 
e. Give help to an accident

f. Providing workers with self-protection tools

g. Preventing and controlling the arising or spreading of temperature, humidity, dust, smog, vapor, gas, wind gusts, weather, light or radiation, sound and vibration

h. Preventing and controlling the onset of illness due to work both physically and psychologically, poisoning, infection and transmission

i. Obtain adequate and appropriate lighting

j. Holds a good temperature and humid air

k. Carry out sufficient air refreshment

1. Maintain cleanliness, health and order

$\mathrm{m}$. Obtaining harmony between labor, work tools, environment, ways and work processes.

n. Secure and facilitate the transportation of people, animals, plants or goods

o. Secure and maintain all types of buildings

p. Secure and expedite the loading and unloading, treatment and storage of goods

q. Prevents dangerous electrical contact

r. Adjusting and perfecting safeguards on work where the danger of accidents is getting higher.

\subsection{Occupational Health}

According to White (Widodo, 2015), Health is a condition where a person at the time of examination does not have any complaints or there are no signs of a disease and abnormality. Occupational health is a health condition that aims for the working community to obtain the highest degree of health, both physically, spiritually, and socially by preventing and treating diseases or health problems caused by work and the work environment as well as general illnesses.

Occupational health (Occupational Health) as an aspect or element of health that is closely related to the work and work environment which can directly or indirectly affect work efficiency and productivity (Tarwaka, 2014).

According to Lidya in Sayuti (2013) the notion of occupational health is a matter that concerns a possible threat to the health of someone who works at a place or company during normal work time. Meanwhile according to Santoso in Sayuti (2013) the notion of occupational health is physical and spiritual health.

An employee who works using certain materials allows a reaction to his health. According to Ridley (2008), Causes of health hazards are:

1. Dust: If inhaled, it affects the lungs, causing pneumonia

2. Toxins: Digestible poisons can affect any body organ, while the body absorbs a number of poisons very quickly

3. Solvent substances: Can enter the body through fluid intake, inhalation of smoke, absorption through the skin

4. Hot and humid: (a) Working at high temperatures and humidity levels can cause seizures/cramps, heat stroke, and fatigue. (b) There are no standards to enforce, but the cold effect of gusts of air can help.

5. Pressure / Stress: Psychological reactions to factors beyond human control such as work demands that are above or below ability, work environment, and relationships with fellow workers or organizations. 


\subsection{Work Accidents}

According to Gunawan and Waluyo (2015), an accident is an (unplanned) and unexpected event that can disrupt the production/operation process, damage property/assets, injure humans, or damage the environment. According to Ridley (2008), accidents do not occur, but are caused by weaknesses on the side of employers, workers, or both. The resulting consequences can lead to trauma for both. For workers, injury can affect personal, family, and quality of life, while for employers, in the form of production losses, time wasted for investigation, and the worst costs for legal proceedings.

According Sedarmayanti (2011) in work accidents can be grouped into 4 namely:

a. Work accidents due to direct work

b. Accident during work time

c. Accidents on the way (from home to work and vice versa, through reasonable roads)

d. Occupational illness.

\subsection{The Establishment of K3RS Policy}

According to Permenkes RI No. 66 of 2016, in the implementation of K3RS, the highest leadership of the Hospital must be committed to planning, implementing, reviewing and improving the systematic implementation of K3RS from time to time in each of its activities by carrying out good K3RS management. Hospitals must comply with applicable laws, rules and regulations. Hospital leaders including the management are responsible for knowing the provisions of the legislation and other provisions that apply to hospital facilities. The Hospital's commitment in implementing K3RS is manifested in the form of: K3RS policies and objectives are determined by the highest leadership of the Hospital and formally and in writing. The policy must be clear and easy to understand and be known by all Hospital human resources both management, employees, contractors, suppliers and patients, visitors, introductory patients, guests and other parties related to appropriate procedures. In addition, all of them are responsible for supporting and implementing the K3RS implementation policy, as well as the procedures that apply in the Hospital while in the Hospital environment. The K3RS policy must be socialized with various efforts at leadership meetings, coordination meetings, other meetings, banners, banners, posters, audiovisuals, and others.

In implementing the K3RS requires an organization that can carry out the K3RS program as a whole and is under the leadership of the Hospital that can determine Hospital policies. The higher class Hospital generally has a greater level of occupational safety and health risks because more and more services, facilities, infrastructure and technology as well as more human involvement in it (hospital human resources, patients, visitors, delivery people, contractors, etc. so).

For the optimal, effective, efficient and sustainable implementation of K3RS, the Hospital forms or appoints a functional work unit that has the responsibility of organizing K3RS. Functional work units can be in the form of separate committees or integrated with other committees, and/or K3RS installations.

\section{5 Definition of Hospital Accreditation}

Hospital Accreditation is an acknowledgment given by the government to hospital management, because it meets the established standards. The purpose of hospital accreditation is to improve the quality of health services, so that is needed by Indonesian people who are increasingly selective and entitled to get quality services. Improving the quality of health services is expected to reduce the interest of the community to seek treatment abroad (KARS, 2012). 
In Permenkes Number 012 of 2012 concerning Hospital Accreditation, it is stated that the definition of hospital accreditation is the recognition of hospitals provided by an independent accreditation provider established by the Minister of Health, after judging that the Hospital meets applicable Hospital Service Standards to improve quality hospital services on an ongoing basis.

In Indonesia, the provision of hospital accreditation at both national and international levels has been regulated by the government through written laws and regulations, namely Law Number 44 of 2009 concerning hospitals article 40 which states that in efforts to improve the quality of hospital services, accreditation must be carried out at least once every 3 years.

\subsection{Public Policy Implementation}

Implementation is the process of implementing policies in order to achieve results. The policy that has been recommended to be chosen by policy makers is not a guarantee that the policy will certainly succeed in its implementation (Subarsono, 2005).

Broadly speaking, the implementation function is to form a relationship that allows the goals or objectives of public policy to be realized as an outcome (final result) activities carried out by the government (Wahab, 2008).

Van Meter and Horn stated that policy implementation links between policy objectives and their realization with the results of government activities where the task of implementation is to build networks that enable public policy objectives to be realized through the activities of government agencies involving various stakeholders (policy stakeholders) (Subarsono, 2005).

The stage of policy implementation can be characterized and distinguished from the policy making stage. Policy making on the one hand is a process that has a bottom-up logic, in the sense that the policy process begins with the delivery of aspirations, requests or support from the community. Whereas policy implementation on the other hand has a top-down logic, in the sense of decreasing abstract or macro policy alternatives into concrete or micro actions (Parsons, 2008).

The policy implementation step can be likened to the actuating function in a series of management functions. Action here is a middle function that is closely related to various initial functions, such as planning (planning), organizing (organizing), revamping personnel (stuffing) and supervision (controlling). As a first step in the implementation is the identification of problems and objectives and policy formulation. The final step in the policy set will be monitoring and evaluation (Abidin, 2002).

\section{Research Methods}

In this study, researchers used a qualitative exploratory method with a case study approach. Qualitative research is research conducted to obtain answers or in-depth information from an informant about a person's opinions and feelings in the form of behavior, perception, motivation and action (Moleong, 2016). This research was conducted at Dr. R. M. Djoelham Regional Hospital in Binjai City because the efforts in achieving accreditation have not been met in accordance with K3RS standards 


\section{Discussion}

Aspects assessed to see the effectiveness of the implementation of the K3RS program with the achievement of compliance with hospital accreditation standards in Dr. R. M. Djoelham Binjai City is communication. Communication is the first requirement for effective policy implementation. An effective policy is that those who carry out decisions must know what to do. Policy decisions and orders must be forwarded to the appropriate personnel before they can be followed. Of course, communication must be accurate and must be understood carefully. In general Edwards discusses three important things in the policy communication process namely transmission, consistency, and clarity. Informants' opinions regarding K3RS program socialization with the achievement of meeting hospital accreditation standards regarding the periodic socialization of K3RS program can be seen in the interview excerpt below:

"Pelaksanaan program K3RS ada 8: saya masih baru menjabat sebagai direktur di rumah sakit ini, untuk sosialisasi program K3RS masih direncanakan untuk dilaksanakan dibulan Maret. Informasi K3RS harus disampaikan kepada seluruh staf yang ada dirumah sakit agar staf rumah sakit mengetahui adanya K3RS dirumah sakit ini dan sudah berjalan" (Informant 1)

"Sosialisasi ada ya, pelaksanaan biasanya kita lakukan 1 tahun sekali, tapi berhubung karena masalah biaya, maka sosialisasi diundur, dan menurut informasi yang saya terima dari direktur sekitar bulan Maret akan diadakan kembali. Sosialisasi ini disampaikan kepada seluruh staf yang ada dirumah sakit agar staf rumah sakit terkhusus kepada unit yang resiko tinggi." (Informant 2)

Policy implementation will be effective if the implementation commands are consistent and clear even though the instructions given to the implementers of the policy have an element of clarity, but if the order is contradictory then the order will not facilitate the policy implementers carry out their duties properly. Explanation of the informant regarding the recipient of information about the K3RS program mechanism can be seen in the excerpt from the interview below:

"Mekanisme dalam mensosialisasikan program K3RS saya sebagai direktur rumah sakit menerima kegiatan yang akan dilakukan oleh K3RS, apabila kegiatan tersebut melibatkan satuan kerja perangkat lainnya, kita akan berkoordinasi dengan satuan kerja tersebut sehingga terjalin kerjasama dalam melaksanakan sosialisasi tersebut.". (Informant 1)

"Mekanismenya ya, biasanya direktur mengundang kami untuk membicarakan hal tersebut, selanjutnya kami memberikan saran kepada direktur siapa saja yang harus dilibatkan. Tetapi untuk simulasi bencana dan kedarutan seperti gempa bumi, maka akan dilibatkan pihak luar, kami akan berkoordinasi dengan pihak tersebut seperti pihak pemadam kebakaran, dan lainlain.". (Informant 2)

Based on the results of interviews with informants, it is known that the mechanism for socialization is done by giving invitations or letters to related units, sometimes the K3RS team directly comes to the unit and socializes K3RS. Explanation of informants about the content and media used for socialization activities such as the following interview excerpts:

"Informasi yang disosialisasikan berupa pengendalian kebakaran biasanya dilakukan dalam bentuk simulasi yang dilakukan secara berkala dan bertahap, mengenai penggunaan alat 
pelindung diri bagi staf yang berkerja diarea berisiko. Media yang digunakan berupa himbauan atau pengumuman, poster, dan video dan alat peraga APAR, APD.". (Informant 1)

"Isi dan materi sosialisasi berupa pengendalian kebakaran, kedaruratan menghadapi bencana gempa bumi, tetapi untuk sosialisasi tentang keamanan saat bekerja kita selalu ada SOP yang harus dijalankan oleh setiap unit untuk prosedur keamanan. Medianya berupa poster, pengumuman atau himbauan, video dan alat peraga lain seperti alat APAR dan APD." (Informant 2)

Explanation of informants about two-way communication and consultation between superiors and subordinates about K3RS as quoted in the interview below:

"Ya, komunikasi K3RS biasanya saya lakukan kepada tim K3RS dan unit Diklat". Untuk ke masing-masing unit pelayanan akan disampaikan melalui tim K3RS dan Diklat (Informant 1)

"'Komunikasi dua arah tentang K3RS biasanya dilakukan oleh direktur kepada tim K3RS ini baik itu pemanggilan ke kantor atapaun pada saat rapat ataupun pertemuan tentang K3RS. Untuk selanjutnya kami meneruskan ke unit pelayanan yang lain" (Informant 2)

Explanation of the informant about the evaluation of the K3RS program as quoted in the interview below:

"Evaluasi program K3 dilakukan tahunan dan ada juga yang harian itu berupa mengenai ketersediaan air, listrik, dan lift, dan kembali kepada program K3RS ada yang sudah dilaksanakan beberapa program diantaranya pengendalian kebakaran dengan menggunakan apar, sudah terpasangnya pendeteksi asap tapi belum seluruhnya, kemudian program kesehatan pegawai namum belum seluruhnya, Nah mengenai program yang belum terlakasana sudah kita anggarkan kembali di APBD 2020.". (Informant 1)

"Evaluasi untuk program K3RS dilakukan tahunan, per enam bulan, dan bulanan. (Informant 2)

The existence of resources in the context of implementing the K3RS program with the achievement of meeting hospital accreditation standards plays an important role in the successful implementation of policies. Without sufficient resources, what is planned will not be the same as what is ultimately implemented. The most important resources in implementing the K3RS program are trained resources. The following is an excerpt from the interview with the informant about K3RS resources in Dr. R. M. Djoelham Regional Hospital in Binjai City:

"Mengenai ketersediaan tenaga K3RS dirumah sakit kita ini masih kurang, namun dari bagian diklat sudah memprioritaskan untuk mengirimkan staf yang ada untuk mengikuti pelatihan sebagai ahli K3RS". (Informant 1)

"Untuk saat ini SDM K3RS di rumah sakit ini untuk yang tersertifikasi dari yang BNSP tu sudah ada beberapa orang dan itu sudah dilatih resmi bahkan sudah ada yang memperpanjang sertifikatnya. Cuma yang namanya pemerintahan, ada rotasi jadi ada yang sudah dilatih, malah keluar dari sini. (Informant 2) 
Based on the results of the interview it can be concluded that in general for the time K3RS HR in this hospital for those who are certified from the BNSP there are already several people and it has been officially trained even there are those who have extended their certificates. But because this hospital belongs to the regional government, there is a rotation or transfer. The Director has also taken the initiative to make requests to the relevant agencies for the addition of K3RS HR. And this hospital strives to be the best in terms of K3RS.

Based on K3RS facilities and infrastructure we can see in the following interview excerpt:

"Sarana dan prasarana dirumah sakit untuk K3RS saya kira sudah cukup ya, seperti ketersediaan air, listrik, genset, lift, Ketersediaan fasilitas untuk K3RS ada seperti ketersediaan APAR, CCTV untuk ruangan khusus seperti ruangan anak, terlihat petunjuk jalur evakuasi, pengunjung rumah sakit diberi identitas sebagai pengunjung serta adanya tangga daurat. Untuk instalasi pengolahan limbah ini harus diperhatikan untuk melindungi sumber daya manusia dirumah sakit, pasien, pendamping pasien, pengunjung juga lingkungan rumah sakit dari potensi bahaya. Akan tetapi kami akan terus berusaha untuk melengkapi kekurangan tersebut. Ketersediaan fasilitas alat pelindung diri dirumah sakit ini cukup diunit masing-masing" (Informant 1)

From the results of the interview it can be concluded that in general the facilities for K3RS are good, but they still need to be improved, which is incomplete must be equipped. The availability of APAR, PPE in each unit, CCTV for special rooms such as children's rooms, visible instructions for the evacuation route, hospital visitors were given an identity as a visitor as well as the emergence of the emergency stairs. For this sewage treatment plant, care must be taken to protect human resources in hospitals, patients, patient companions, visitors and hospital environments from potential hazards.

Disposition is the character and characteristics of the K3RS program implementers, such as commitment, honesty, democratic nature. Disposition is an important factor in implementing effective policies. If the K3RS program implementer has a good disposition, then he can run the policy as well as desired by the policy maker. When the implementer has a different attitude or perspective from the policy maker, the policy implementation process also becomes ineffective. Explanation of the informant regarding disposition can be seen in the following interview excerpt:

"Saya sangat mendukung sekali adanya program K3RS dan saya mempunyai komitmen untuk mengirim staf yang ada dirumah sakit untuk dilatih sebagai ahli K3RS." (Informant 1)

"Bisa dibilang 50:50. Ada yang sudah unit-unit yang mendukung penuh, ada yang 70\% ada yang masih 50\%. Semua bervariasi, karena kendala perilaku dan mainset-mainset mereka sendiri. Dan akan bertahap pelan-pelan (Informant 2).

Based on the results of interviews with informants, it is known that they strongly agreed and accepted the K3RS program positively. Because by implementing this K3RS Program they can work safely and comfortably.

Another aspect of disposition is the condition of the work environment that can be seen in the interview excerpt below:

"Saya selaku pimpinan merasa lingkungan kerja di RS kondusif" (Informant 1) 
"Jadi memang standart setiap SDM yang ditempatkan terutama ditempatkan di unit unit yang beresiko tinggi, itu kita monitor kesehatannya dari sebelum bertugas, awal bertugas, sampai selesai bertugas terus kita evaluasi kesehatannya. Seperti bagian radiologi, kita evaluasi apakah ada dampak terhadap tubuhnya setelah bekerja. Pemeriksaan kesehatan untuk screening hepatitis sudah kita lakukan dan vaksinasi. Untuk pemeriksaan berkala masih belum kita laksanakan. (Informant 2).

Based on the results of interviews with informants, it is known that the conditions of the work environment are conducive, comfortable, the completeness of APAR and APD equipment is complete so that the work environment is safe, but there are some units that still feel uncomfortable because the conditions of the room are a bit narrow, so it is necessary to increase the area of the room and the K3RS program is what makes them work quietly and comfortably.

Bureaucracy is one of the most often and even as a whole body implementing policies. The organizational structure in charge of implementing the policy has a significant influence on the policy implementation.

Explanation of informants regarding bureaucracy to support the implementation of K3RS in Dr. R. M. Djoelham Regional Hospital in Binjai City based on the mechanism of delegation of authority of each individual in the K3RS program management organization can be seen in the following interview excerpt:

"Jika kebawah pendelegasian sesuai dengan tupoksi kerja staf dimasing-masing unit dan sesuai dengan SK yang sudah diberlakukan (Informant 1)

"Jadi memang standart setiap SDM yang ditempatkan terutama ditempatkan di unit unit yang beresiko tinggi, itu kita monitor kesehatannya dari sebelum bertugas, awal bertugas, sampai selesai bertugas terus kita evaluasi kesehatannya. Seperti bagian radiologi, kita evaluasi apakah ada dampak terhadap tubuhnya setelah bekerja. Pemeriksaan kesehatan untuk screening hepatitis sudah kita lakukan dan vaksinasi. Untuk pemeriksaan berkala masih belum kita laksanakan. (Informant 2)

Based on the results of interviews with informants, it is known that the delegation of authority of each individual in the K3RS program management organization is in accordance with the work duties of staff in each unit and in accordance with the decree that has been applied. every Human Resources placed is primarily placed in high-risk units. There is also a delegation of tasks to other colleagues if the person is unable. Every Human Resources in the work units is monitored their health from before serving, beginning to serving, until finished serving, and their health is continuously evaluated.

Explanation of the informant regarding the obstacles faced in organizing the implementation of K3RS can be seen in the following interview excerpt:

Kendala nya karena rumah sakit ini rumah sakit pemerintah, pendanaan utk program K3RS harus dianggarkan sehingga tidak semua program bisa berjalan sekaligus (bertahap). Kendala yang ada dalam program K3RS adalah dari 10 program hanya 3 yang sudah dilaksanakan yaitu untuk program selanjutnya sudah tertampung di APBD 2020" (Informant 1) 
"Kendalanya untuk melaksanakan monitoring evaluasi ini lagi-lagi ada kendala anggaran dari rumah sakit. Masalah lain mungkin mudahya... budaya dari individunya, karena mereka sudah bekerja sesuai dengan kebiasaan mereka yang aman-aman saya. Banyak orang yang menganggap itu tidak penting. Masalah utama bukan di anggaran tetapi bagamana mengubah mainset atau kebiasaan orang-orang tersebut." (Informant 2)

Based on the results of interviews with informants, it is known that the obstacles faced in organizing the implementation of K3RS are budgetary issues so that not all programs can run at once (gradually). Another obstacle is the culture of the individual, because they have worked according to their safe habits. So many people consider it unimportant. This is a challenge for the K3RS how to change the mainset or habits of these people. In addition, another obstacle is that this hospital is a government hospital, so there will be a rotation of tasks, such as skilled and certified human resources must be transferred to another hospital.

\section{Conclusions}

Based on the results of the study it can be concluded that K3RS (Occupational Health and Safety) implementation in Dr. R. M. Djoelham Regional Hospitas of Binjai City based on category communication is good. This is indicated by despite the lack of budget in conducting socialization and simulation, but they continue to carry out socialization to related units, especially those with high risk with K3RS.

The implementation of K3RS based on human resources category is lacking, marked by the presence of experts who are experts in K3RS that must be transferred to other hospitals. The implementation of K3RS is based on the disposition of good categories marked by all employees in the hospital who are positive about K3RS and committed to always support the implementation of K3RS. The implementation of K3RS based on bureaucracy has been well marked by coordination and delegation of authority between units well established in accordance with their respective duties and functions.

\section{References}

Abidin, Z.S., 2002. Kebijakan Publik, Edisi Revisi, Yayasan Pancur Siwah. Jakarta.

Basrowi \& Suwandi, 2008. Memahami Penelitian Kualitatif. Rineka Cipta. Jakarta.

BPJS, 2017.Ketenagakerjaan Catat 3.576 kasus Kecelakaan Kerja di Riau dan Sumbar.Dikutip dari www.bpjsketenagakerjaan.go.id.

Creswell, John. W, 2014.Penelitian Kualitatif \& Desain Riset Memilih diantara Lima Pendekatan Edisi Ke-3, Pustaka Pelajar.Yogyakarta.

Gemely, 2018.Implementasi Sistem Manajemen Keselamatan dan Kesehatan Kerja PT. Pelindo IV (Persero) Terminal Petikemas Makassar.

Gunawan dan Waluyo. 2015. Risk Based Behavioral Safety Membangun Kebersamaan Untuk Mewujudkan Keunggulan Operasi.PT Gramedia Pustaka Utama, Jakarta.

Ibrahim. H, Damayanti, S.D.A.(2017). Gambaran Penerapan Standart Keselamatan dan Kesehatan Kerja Rumah Sakit Umum Daerah Haji Makassar, Public Health Science Journal, 9(2), 160-173.Universitas Islam Negeri Alauddin Makassar.

Indiahono, 2009.Kebijakan Publik Berbasis Dynamic policy Analisys. Gava Media. Yogyakarta.

Irmawati, 2019. Kesehatan dan Keselamatan Kerja (K3) di Bagian filing. Jurnal Manajemen Informasi Kesehatan Indonesia Vol. 7 No.1 Maret 2019 ISSN: 2337-6007.

Ismail, 2018.Penerapan Kesehatan dan Keselamatan Kerja Rumah Sakit (K3 RS), dikutip dari 
Penerapan Kesehatan dan Keselamatan Kerja Rumah Sakit (K3RS).

Ivana, Azza, 2014. Analisa Komitmen Manajemen Rumah Sakit (RS) Terhadap Keselamatan

Dan Kesehatan Kerja (K3) Pada RS Prima Medika Pemalang. Fakultas Kesehatan Masyarakat UNDIP. Semarang.

Komite Akreditasi Rumah Sakit (KARS). 2012. Instrumen Akreditasi Rumah Sakit Standar

Akreditasi Versi 2012- Edisi 1. Komisi Akreditasi Rumah Sakit. Jakarta.

Kelloway et.al, 2012.Management of Occupational Health and Safety Fifth Edition, Nelson Education Ltd, USA.

Komara, 2014. Analisis Implementasi Kebijakan Pengelolaan Bahan Berbahaya dan Beracun

(B3) Pasca Akreditasi JCI di RSUPN dr.Cipto Mangunkusumo.

Natalina, 2018. Pedoman Wawancara "Analisis Implementasi Kebijakan Pelaksanaan IVA

Test Untuk Deteksi Dini Kanker Serviks di Puskesmas Batu Anam”. Tesis FKM

Institut Kesehatan DELI HUSADA Deli Tua.

Parson, Wayne, 2008.Pengantar Teori \& Praktik Analisis Kebijakan Public Policy. Jakarta.

Purnama, 2018.Analisis Risiko Pekerjaan Menggunakan Metode Hirarc (Hazard Identification,

Risk Assessment And Risk Control) Pada Bagian Pelayanan Kehandalan Distribusi

Listrik di PT. Haleyora Power Kota Padang Tahun 2017.Diploma thesis, Universitas

Andalas.

Rachmawati, 2008. Manajemen Sumber Daya Manusia,. ANDI. Yogyakarta.

Ridley, John.,2008. Ikhtisar Kesehatan \& Keselamatan Kerja Edisi Ketiga. Erlangga. Jakarta.

Rivai, Veithzal dan Sagala, Ella Jauvani.2010. Manajemen Sumber Daya Manusia untuk Perusahaan dari Teori ke Praktik. PT Raja Grafindo, Jakarta.

Salmawati, L. dkk (2015).Hubungan Penerapan Sistem Manajemen Keselamatan Dan Kesehatan Kerja Dengan Motivasi Kerja Dan Stres Kerja Pada Perawat Di Rumah Sakit Umum Anutapura Palu. Jurnal Manajemen Pelayanan Kesehatan18(1), 4 6.Universitas Tadulako Palu.

Sarastuti, 2016.Analisis Kecelakaan Kerja di Rumah Sakit. Universitas Gadjah Mada. Yogyakarta.

Saryono \& Anggraeni, D.M., 2013.Metodologi Penelitian Kualitatif dan.Kuantitatif dalam Bidang Kesehatan. Nuha Medika, Yogyakarta.

Sayuti, A. J, 2013. Manajemen Kantor Praktis. Alfabeta, Bandung.

Sedarmayanti.2009. Manajemen Sumber Daya Manusia dan Produktivitas Kerja. Refika Aditama. Bandung.

Subarsono, 2005. Analisis Kebijakan Publik Konsep, Teori dan Aplikasi. Pustaka Pelajar. Yogyakarta.

Sugiono, 2013. Metode Penelitian Kuantitatif, Kualitatif, dan R\&D. Alfabeta. Bandung.

Sutopo, 2006. Metodologi Penelitian Kualitatif : Dasar teori dan Terapannya dalam Penelitian. Universitas Sebelas Maret. Surakarta.

Tarwaka, 2014.Keselamatan dan Kesehatan Kerja : Manajemen dan Implementasi K3 di Tempat Kerja. Harapan Press; Surakarta.

The National Safety Council (NSC), 2015.Injury Facts 2015 Edition. USA.

Wahab, S. 2008. Pengantar Analisis Kebijakan Publik. Universitas Muhammadiyah Malang. Malang.

Widodo, SE., 2015. Manajemen Pengembangan Sumber Daya Manusia. Pustaka Pelajar, Yogyakarta.

Yin, Robert K., 2011. Studi Kasus: Desain dan Metode.PT. Rajagrafindo Persada.

Yunita, Ajeng Retno, 2016. Analisis faktor-faktor kebijakan dalam implementasi program keselamatan dan kesehatan kerja rumah sakit (k3rs) di instalasi gawat darurat rumah sakit umum daerah kota Semarang. Fakultas Kesehatan Masyarakat UNDIP. Semarang. 